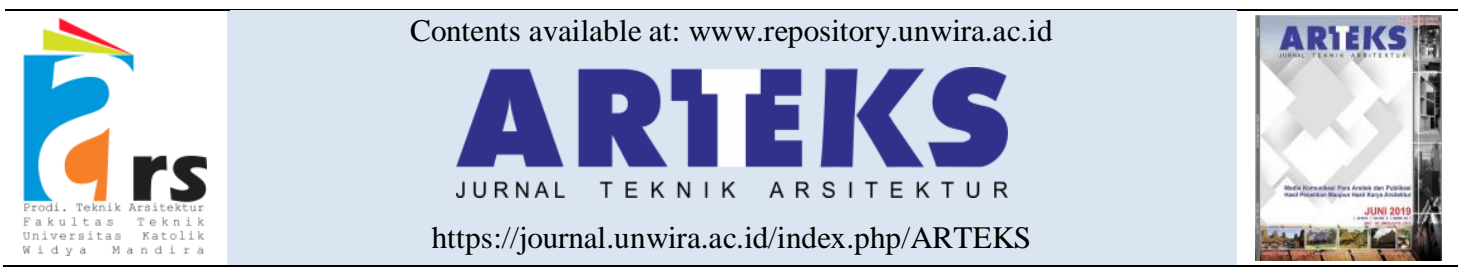

Research paper

doi: 10.30822/arteks.v5i3.575

\title{
Phenotype and genotype Malay traditional house in West Kalimantan
}

\section{Indah Kartika Sari* (i), Wiendu Nuryanti, Ikaputra}

Department of Architecture and Planning Engineering,

Facultry of Engineering, Universitas Gadjah Mada

Jl. Grafika, no. 2, Yogyakarta, Indonesia

\begin{tabular}{|c|c|}
\hline ARTICLE INFO & ABSTRACT \\
\hline $\begin{array}{l}\text { Article history: } \\
\text { Received June 06, } 2020 \\
\text { Received in revised form June } 202020 \\
\text { Accepted July 01, } 2020 \\
\text { Available online December 01, } 2020\end{array}$ & $\begin{array}{l}\text { The rapid growth in development has tremendously influenced the } \\
\text { environment and its architectural diversity in every region } \\
\text { worldwide, including Indonesia. In addition, the vulnerability } \\
\text { associated with architectural forms' transformation has an impact } \\
\text { on possible survival or extinction rate of identities. This is prevented } \\
\text { bv collecting identity ata }\end{array}$ \\
\hline $\begin{array}{l}\text { *Corresponding author: Indah Kartika Sari } \\
\text { Department of Architecture and Planning } \\
\text { Engineering, Faculty of Engineering, } \\
\text { Universitas Gadjah Mada, Indonesia } \\
\text { Email: indah.kartikasari120988@ gmail.com } \\
\text { ORCID: 0000-0002-0397-8931 }\end{array}$ & $\begin{array}{l}\text { phenetype were adopted in architecture. The genotype is an abstract } \\
\text { relational model that regulates the arrangement of space, and the } \\
\text { principle of organization, while phenotype is its realization in the } \\
\text { physical environment. Genotypes are genetically inherited; } \\
\text { therefore, it forms the identity of a society. Data were obtained from } \\
69 \text { traditional Malay houses in eight regions of West Kalimantan } \\
\text { using the Levi Strauss structuralism and spatial configuration. } \\
\text { External and internal structure analyses were carried out, through } \\
\text { spatial configuration to determine the basic pattern and variations } \\
\text { in phenotypes and genotype, respectively. The result showed that the } \\
\text { value and meaning of the principle of spatial arrangement in } \\
\text { traditional Malay houses in West Kalimantan, in the form of gender } \\
\text { classification and environmental cleanliness/dirtiness, have been } \\
\text { genetically inherited. }\end{array}$ \\
\hline
\end{tabular}

\section{Introduction}

Genetics is a branch of biology associated with the study of genes and heredity organisms. In the 1900s, Mendel stated the inheritance law in terms of genotypes and phenotypes. Meanwhile, at the beginning of the 20th century the term genotype and phenotype in biology was adopted by Hillier and Leaman into architecture (Güney 2007). According to Bafna (2012), the term genotype is expressed as a description of physical material formed from DNA and passed on to an organism by its parents, while phenotype is the physical form (Bafna 2012). In architecture, genotypes are abstract relational models that govern space arrangement and the organizing principles of the underlying phenotypes in the form of artifacts
(Sari, Nuryanti, and Ikaputra 2020). Cultural information is transferable from one person to another through verbal and object languages. In 1976, an evolutionary biologist named Dawkins introduced the term meme as a unit that carries transferable cultural information through imitation.

Furthermore, this term has been used in the fields of evolution, religion, and myth. Theoretically and philosophically, buildings are artifactual symbols that store cultural information in human habitats (Lee 2017). This is in line with Heidegger's (1971) research, which stated that buildings are symbols of innate human qualities and cultural communities (Heidegger 1971). It is described as traces of cultural information that is considered to be the language of artifacts. 
Therefore, it is essential to possess an adequate understanding of the general units or architectural components of artifacts language by tracing its spatial patterns. Every human uses space differently, and following their needs and desires. It is necessary to understand the functions of space user's behavior and the form, which originates from the walls, roof, and floor of the space user. Therefore, this is one of the reasons archetypes in spatial layouts were initially referenced when identifying buildings as language artifacts (Arinto 2018).

Seo (2012) stated that traditional dwellings in Korea were modernized into multi-storey buildings. However, the modern house still maintains the old features through different floor levels, limiting the boundary between the inner and outer environments. Furthermore, Seo (2012) reported that a house is a medium that depicts the cultural values and beliefs of a community. The term hidden dimension was used to reveal the hidden values in physical occupancy (Seo 2012). In 2017, Seo conducted further research on traditional houses and modern apartments in Malaysia. The research showed that floor plans are used to determine genotypic elements that survived on old culture (Seo 2017). Also, it is graphically represented and analyzed to filter out spatial elements. Therefore, through this interpretation of similarities, the special nature of culture from the past is revealed (Seo 2012). According to Dyda (2015), in this modern era, the preservation of individual distinctiveness and identity of architecture is mandatory (Dyda 2015).

Similarly, Ibrahim (2016) stated that a contemporary architect is tasked to consider old and current culture, with an adequate understanding of the practical approach to revive the tradition (Ibrahim 2016). The global environmental development tends to influence the identity of architectural diversity in every region in Indonesia. In addition, the vulnerability associated with the transformation of architectural forms has an impact on possible survival or extinction rate of identities. This is achieved by collecting data through the analysis of phenotypes and genotypes, with the results used as a reference or guideline in sustainable development. Furthermore, the architectural identity is traced through an analysis of phenotype variations to determine the genotypes that contain philosophical meaning and re-realize the original phenotype as a database of sustainable development.
Genotype and phenotype in architecture

The syntactic space methodology adopted the terms genotypes and phenotypes from biological disciplines and applied them to social science in general and architecture in particular. According to Hillier and Leaman (1974), a genotype is an abstract relational model that regulates the arrangement and organization of space and its principle (Hillier and Leaman 1974). In contrast, a phenotype is the real realization of genotype in the physical environment, such as architectural artifacts. According to a research carried out on space syntax theory, Hillier (1996) stated that genotype is a reflection on spatial organization and the nature of social and cultural patterns (Hillier 1996). According to Hanson (1998), spatial genotypes are determined through the identification of similarities and differences in the internal configuration of buildings (Hanson 1998). One of the most common ways to analyze genotypes is to observe the culture built into residential space patterns, which is similar to the kitchen position. In addition, the spatial configuration shows cultural genotype as a result of encoding social meaning in architecture (Hillier 1996).

Cultural structures are passed down from generation to generation, with large variations at an observable level. According to biologists, the stable structure underlies this generic inheritance is called oxygenotype, as opposed to the phenotype observed in a variety of ways (Hillier and Leaman 1974).

Genotypes are broadly defined as features or phenomena that persist over time and repeatedly cloned. Byun and Choi (2016), defined the domestic spatial genotype as a pattern commonly appears in some cases. In architecture, resistance to change has strong roots in structures called archetypes, which are considered as zero points in architecture (Byun and Choi 2016). It also forms a framework of resilience, where changes occur in three Vitruvius principles, namely function, technology, and aesthetics. Ledent (2017) reported that to understand the archetypes in the specific scope of local architecture, the building design needs to be examined by studying the typological analysis (Ledent 2017).

Interaction of genotype and environmental influences of phenotype

In biology, phenotypes represent the universal consequences of genotype-environmental interactions as well as all living organisms. 
Garrod (1902) was one of the first scientists that noted the environment's (E) ability to modify the effects of genes on phenotypes (Baye, Abebe, and Wilke 2011).

$$
\begin{aligned}
& \mathrm{P}=\mathrm{G}+\mathrm{E} \\
& \text { Explanation: } \\
& \mathrm{P}=\text { Phenotype } \\
& \mathrm{G}=\text { Genotype } \\
& \mathrm{E}=\text { Environment }
\end{aligned}
$$

The phenotype develops from the interaction among organisms and the environment. This occurs from the beginning of the growing stage until the end of life. This condition raises many additional challenges in quantitative analysis. Therefore, it is almost impossible to record biological systems and their environments in the many spatial and temporal dimensions needed to understand certain phenotypes (Pieruschka and Schurr 2019). The biological presence of phenotypic plasticity in plants is part of its adaptation to certain environments. For example, plant phenotypes exposed to limited environments such as drought, are generally smaller and often adjust their structure (shoots and roots) and physiology (Pieruschka and Schurr 2019). Similarly, in architecture, a house's shape tends to adapt to the occupants and environment to produce many variations.

\section{Method}

This study uses the Levi Strauss's Structuralism paradigm by observing surface and internal structures. The paradigm assumes that the entire universe is a world of symbols and meanings. This approach is elaborated with the structuralism paradigm, which has an external and internal structure in the form of shape/function, and the cultural phenomena studied. Furthermore, the external and internal structures of the Levi Strauss paradigm are considered as a form of phenotype and genotypes. The typology of Malay traditional house phenotype in West Kalimantan was carried out to determine the shape's attributes, namely archetypes or basic patterns through space syntax with the spatial configuration analysis obtained using the justified graph (j-graph). After discovering the spatial configuration, an archetype or basic pattern is found, which is repeated and used to identify the genotype obtained. According to previous studies, a genotype is an abstract model that is imitated in architectural communication. It is interpreted using spatial patterns in buildings, therefore the underlying 'social logic' can be understood. Space creates a special relationship between function and social meaning in buildings. Hillier and Hanson (1984) stated that spatial planning in buildings is also an arrangement of relationships between people (Hillier and Hanson 1984). In justified graph analysis, the first stage is carried out by quantifying the interiors of buildings. Patterns are seen through permeability or space depth systems, as well as spatial arrangements and entrances used to access human movement in space.

Notkin (1988) reported that the analysis phase is used to determine the meaning of genotypes (Notkin 1988). This is graphically carried out by analytically modeling the geometry of space and parts between these spaces and the external environment. Figure 1 shows the framework of the method in this study: 


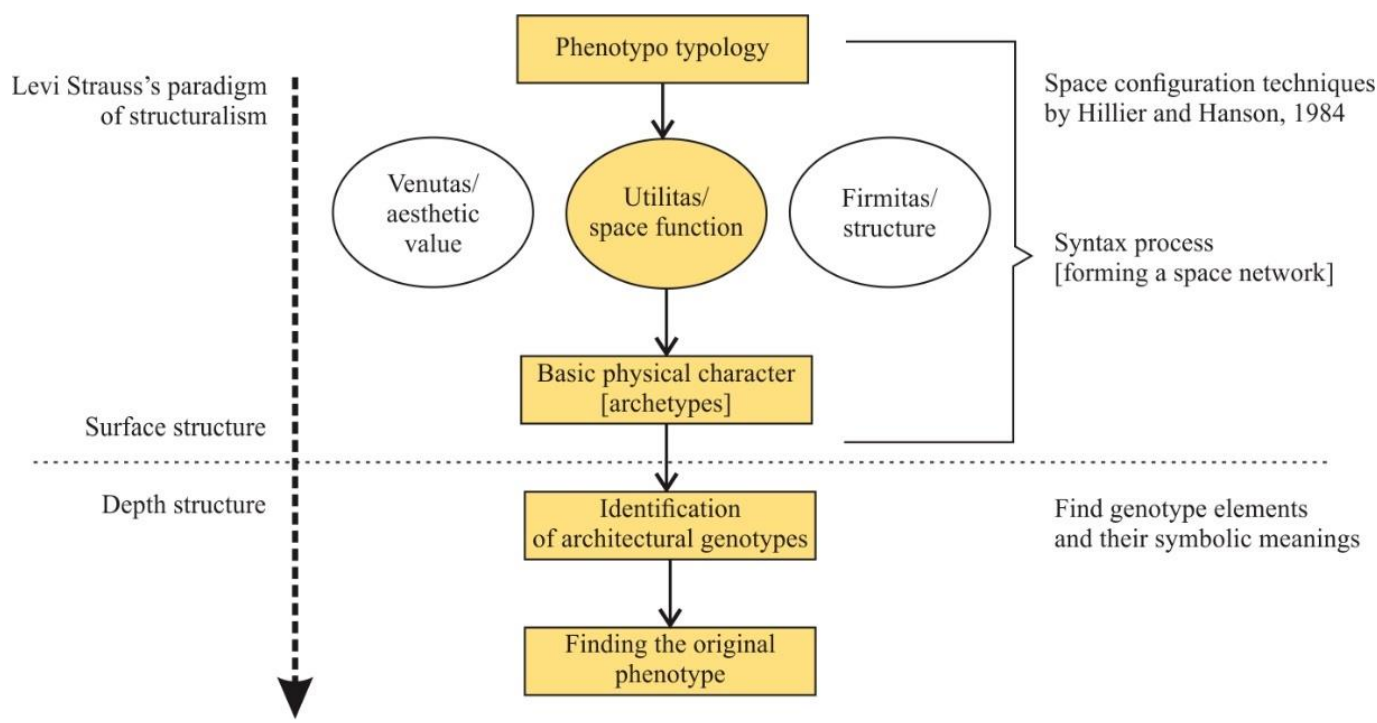

Figure 1. Research method

Research location

Data were obtained from 69 traditional Malay houses in eight regions of West Kalimantan using the Levi Strauss structuralism and spatial configuration, as shown in figure 2 . The traditional Malay houses consist of: limas, wire, and godang cut type of houses. The sample observation image is shown in figure 3.

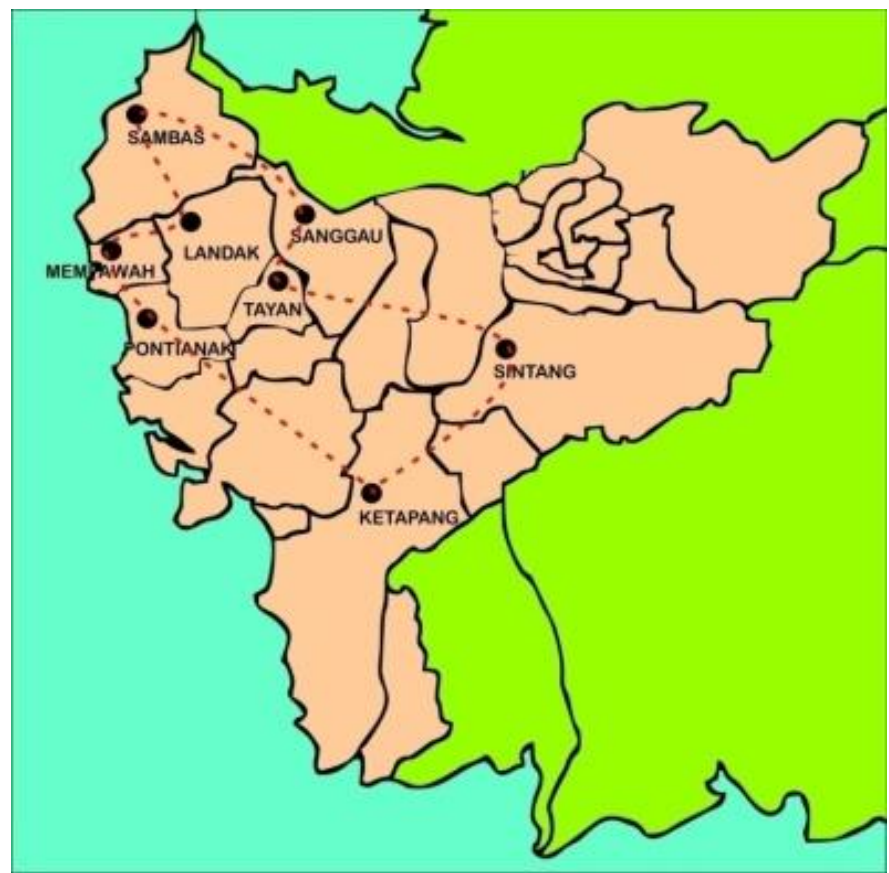

Figure 2. Research location 


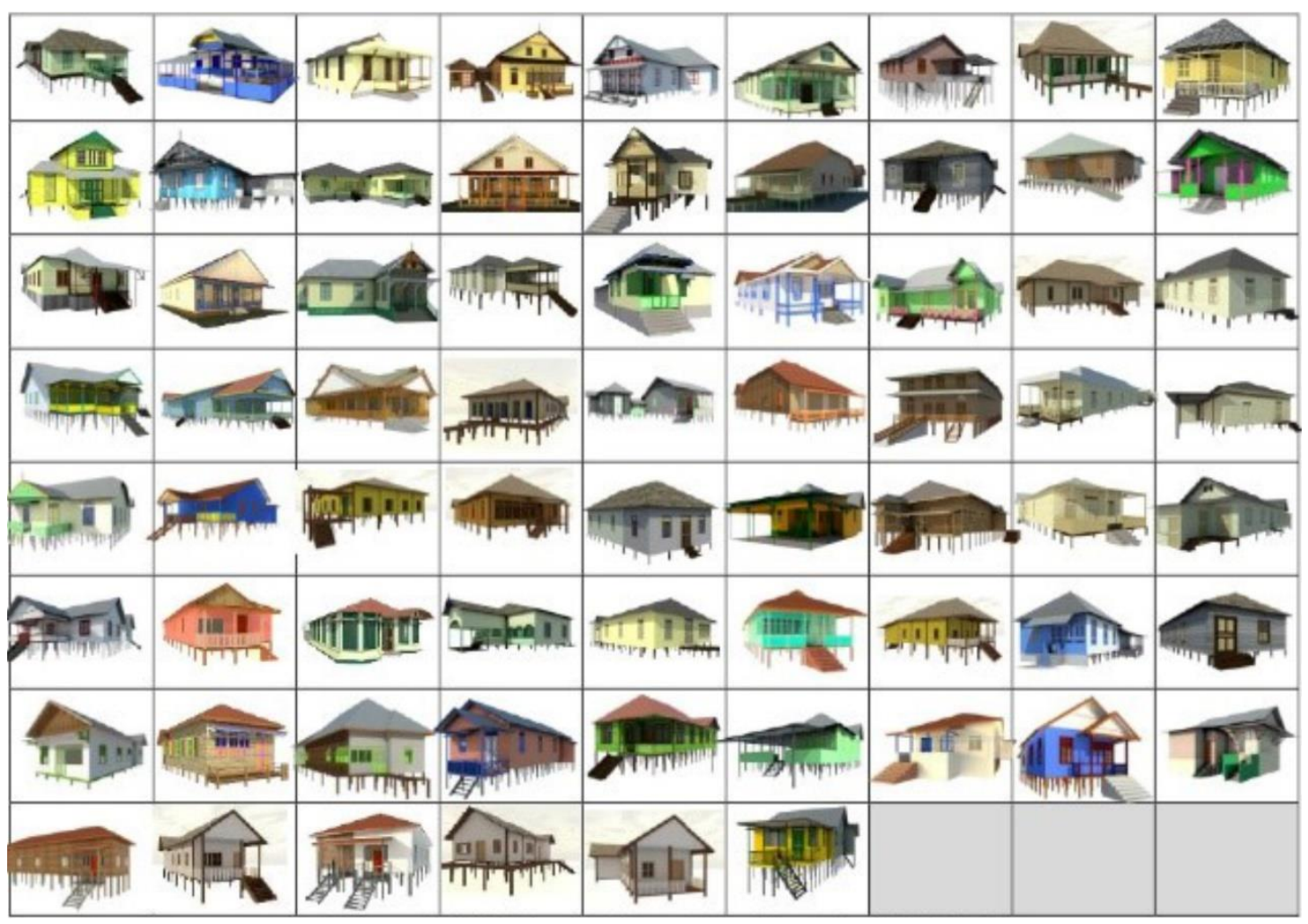

Figure 3. Research sample

\section{Result and discussion}

Consistency was found in all three types of houses located in Malay. Table 1 shows the J-graph analysis in 8 regions with 69 cases using the Space Syntax. The pattern, which is always passed down from generation to generation, is in the form of a room arrangement, consisting of a terrace, front (porch), living room, cubicles, middle room (pelantaran), and kitchen with a side terrace or back porch.

Table 1. Space syntactic

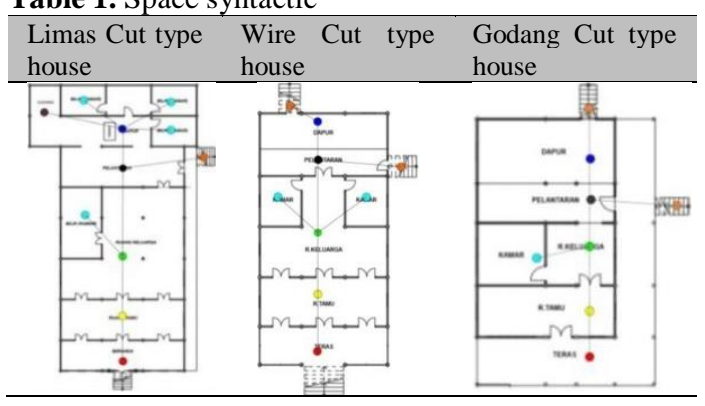

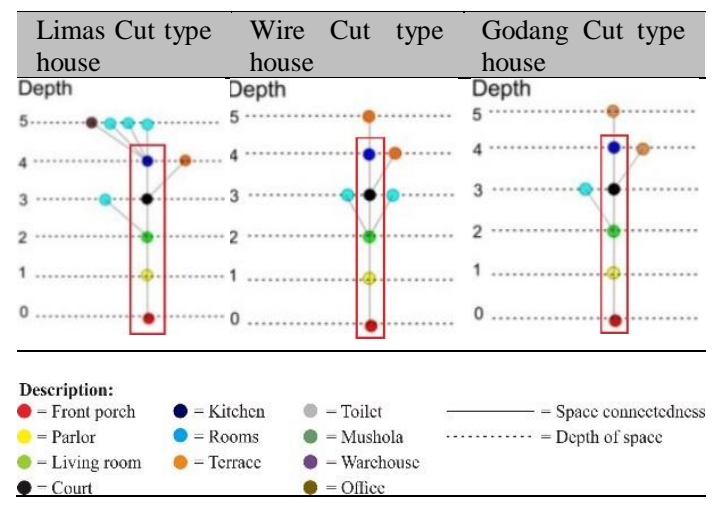

Table 2 shows the syntactic analysis of the wall with consistency in opening the door for occupants. The 3 door openings in each wall of the central, living, and family rooms of the 29 out of the 48 houses where limas and wire cut type. Meanwhile, the cutting-edge type does not have the characteristics of 3-door openings in these spaces, while those with syntax wall and door boundaries in a total sample of 69 houses. It shows that the resident of Malay houses in West Kalimantan maintain visual privacy. 
Table 2. Syntax of wall openings

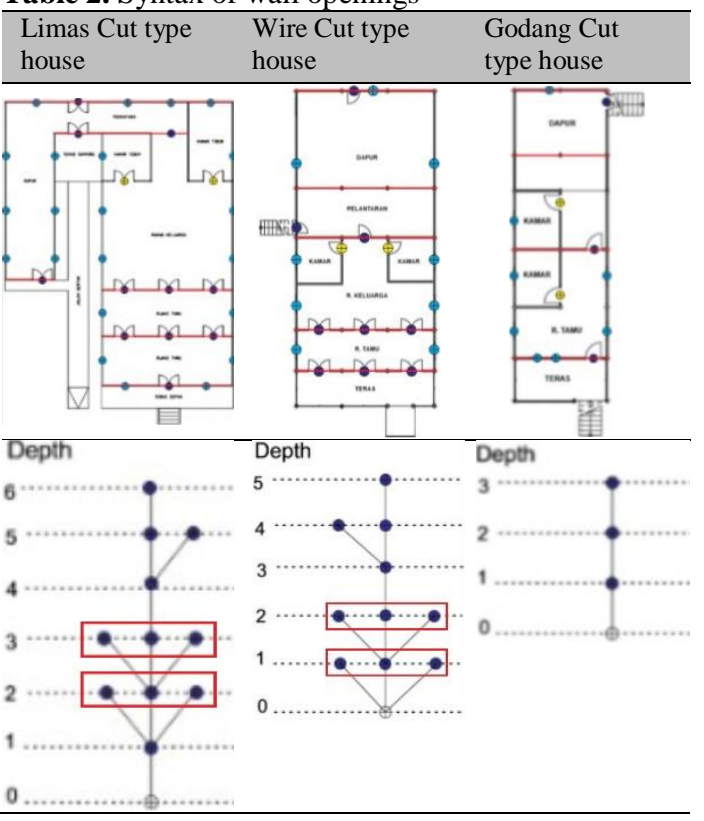

Table 3 shows that the roof's syntax is analyzed from the number and depth of shaded space syntax. A total of 51 dominant patterns where found in 69 sample houses of the various types. This pattern shows that there are no types of roofs used in the main house (front porch, living room, family room, bedroom), middle room (pelantaran) (pelantaran and side porch), kitchen, and back terrace.
Table 3. Syntax of the roofs

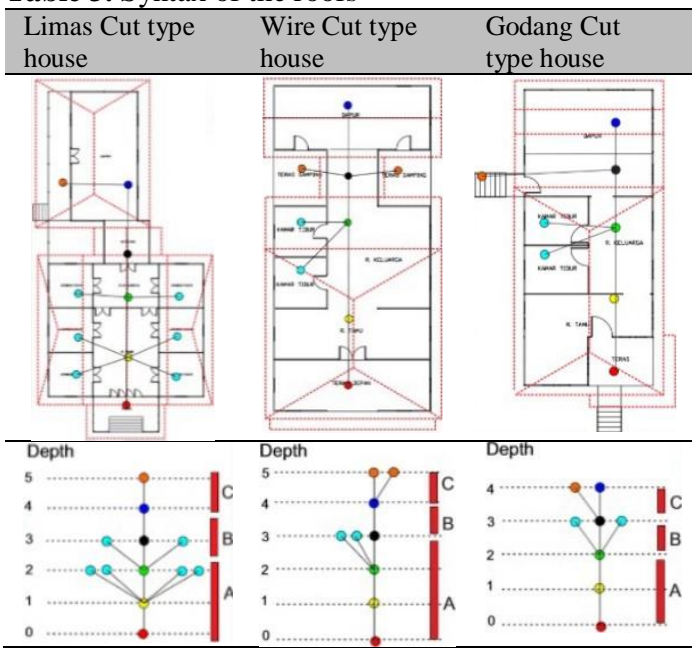

Eliade (2003) stated that an object or an action is real when repeated or imitated, this means that humans feel real when imitating from archetypes (original patterns) (Eliade 2003). In this study, the most dominant pattern is a reference to the traditional Malay house pattern in west Kalimantan, as shown in figure 4. From the depth of space, the meaning of public and private space in buildings is traced. The basic pattern contains genotypes as the principle of spatial arrangement with genotype is considered the most stable structure. The front terrace, also known as the front porch, is the beginning of rooms in a Malay house in West Kalimantan. At a Malay house in West Kalimantan, male and female guests usually enter through the front and back porch, respectively. The front porch to the living room (middle porch) is limited by walls and doors in one depth of space. The living room is an area where male guests are received when celebrating an event. From there, they proceed to the family room, which is limited by walls and doors. Every door on the front, middle and back porch is always covered up by a curtain, therefore boundaries are always maintained. 


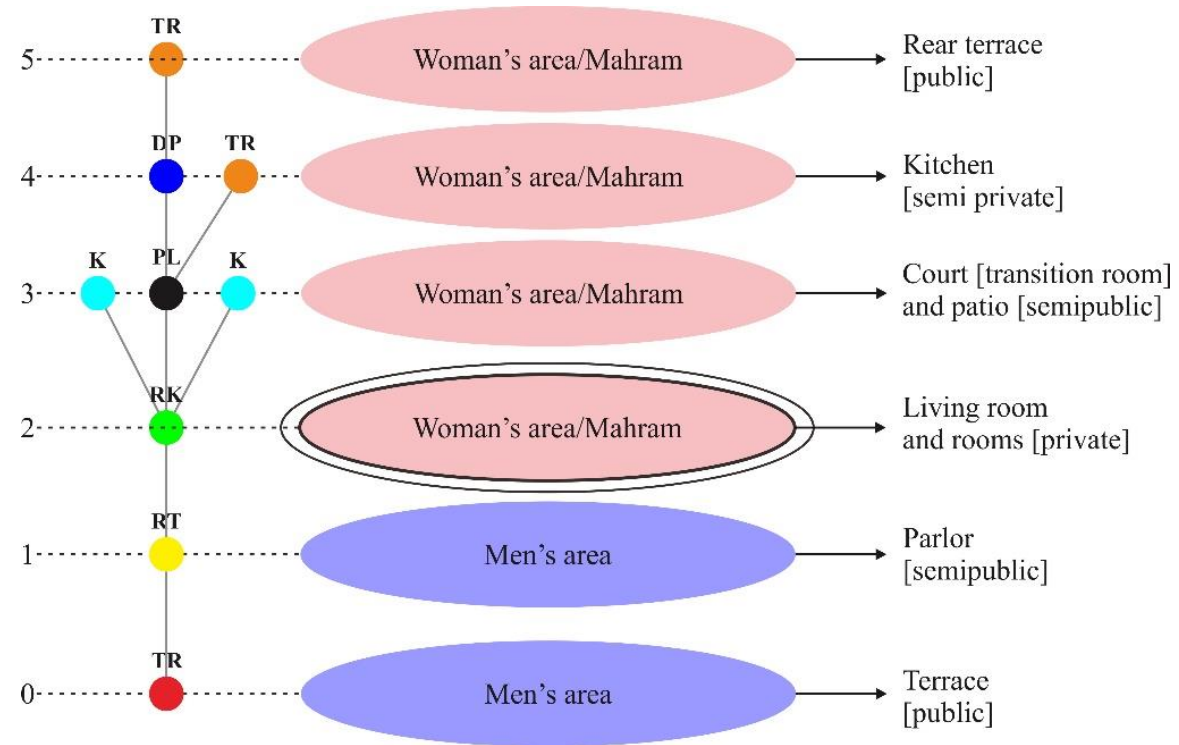

Description:

Front porch $[$ terrace $]=\mathrm{TR}$; Central foyer $[$ parlor $]=\mathrm{RT}$; Rear porch [living room $]=\mathrm{RK}$

Both $[$ rooms $]=\mathrm{K}$; Court $=$ PL; Kitchen $=$ DP

Figure 4. The depth of space from basic pattern

The result obtained from the findings of space, walls, and roof syntactic showed an abstract model referenced to the traditional Malay houses in West Kalimantan. Parents are responsible for the welfare of their children, both boys, and girls. The limitation of mahram in a traditional Malay house is a visual privacy factor. The three main things that hold parents in building a family include the religious system, which is the relationship between humans and God. The principle of the spatial arrangement of both walls and openings as a mahram boundary or floor height level divides the dirty and sacred zone. The social system builds a system of openness in the relationship between occupants and neighbors. Hospitality in life looks at the door opening is a symbol of residents' friendliness used to welcome guests into the house. Furthermore, the environmental system, which consists of human and environmental connectivity, is seen from space such as terrace, suitable with the river path, and the placement of canoe.

The philosophy of space arrangement is closely related to the life way of the Malay people of West Kalimantan, which firmly holds Islamic rules in the principle of organizing space. The hospitality principle and maintaining privacy or boundaries between men and women become the foundation in their homes. Islam is a religion with a strong emphasis on power relations in society or the ummah. This is the basis of the importance of hospitality in a Muslim's home. Visual privacy in the Malay house greatly protects female residents, and in addition to the segregation between public and private life, there is also gender segregation.

Furthermore, there are similarities in the three types of Malay houses due to its adherence to Islam. Therefore, the home's activities are interpreted in their relationship with fellow human beings and God, which is known as habluminannas and habluminallah in Islam. The levels division on the floor of the main house, middle room (pelantaran), and secondary home (kitchen) are also based on this because the main house is considered a sacred space for worshipping. Therefore, before entering the house, residents need to clean themselves by washing their hands and feet. Figure 5 outlines the arrangement and principles of organizing spaces or genotypes in Malay houses in West Kalimantan.

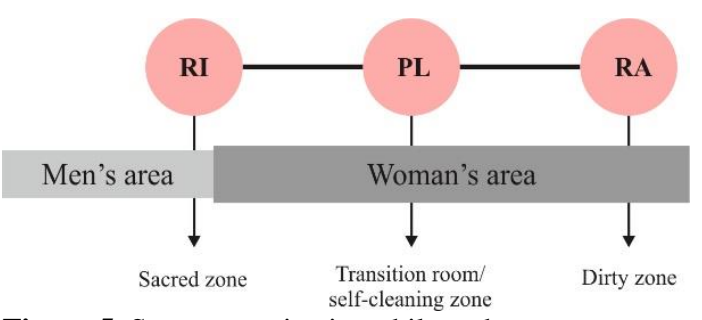

Figure 5. Space organization philosophy as genotype 
The search for phenotypes variations is used to determine basic patterns and genotypes. This is further preceded by the representation of the original phenotypes to facilitate understanding architectural identity. Table 4 shows pictures of the original phenotypes in Malay houses in West Kalimantan.

Table 4. Original phenotypes in Malay houses Limas Cut Malay house

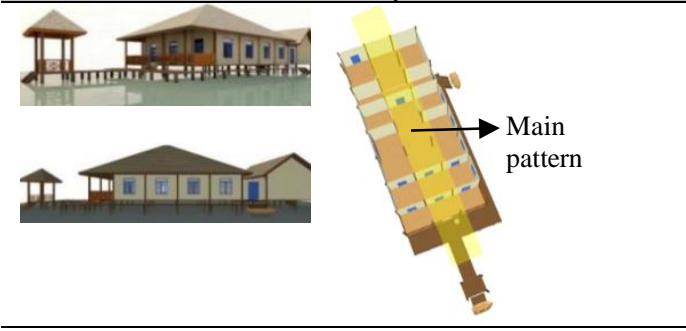

This figure consists of the main, boarding, and secondary houses. It has a pyramid-shaped roof, with a core room in the form of the front porch, living room, family room, middle room (pelantaran) and kitchen. The front terrace and living rooms consist of male and family rooms, while the middle and kitchen are women's sections. The main house is a clean zone, the middle room (pelantaran) is a transition zone for self-cleaning, and the secondary home is a dirty zone.

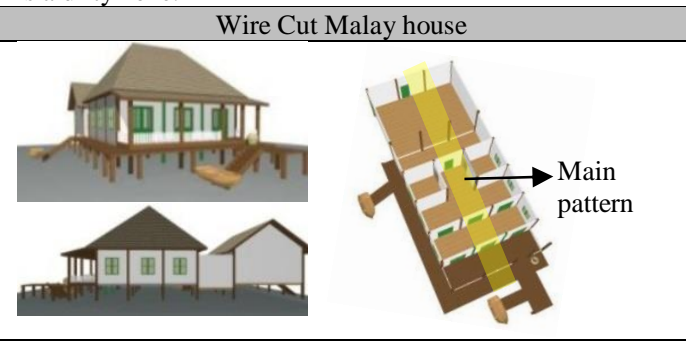

This figure consists of the main, boarding, and secondary houses. It has a pyramid-shaped roof, with a core room in the form of the front porch, living room, family room, middle room (pelantaran) and kitchen. The front terrace and living rooms consists of male and family rooms, while the middle room and kitchen are women's sections. The main house is a clean zone, middle room (pelantaran) is a transition zone for self-cleaning and the secondary home is a dirty zone.

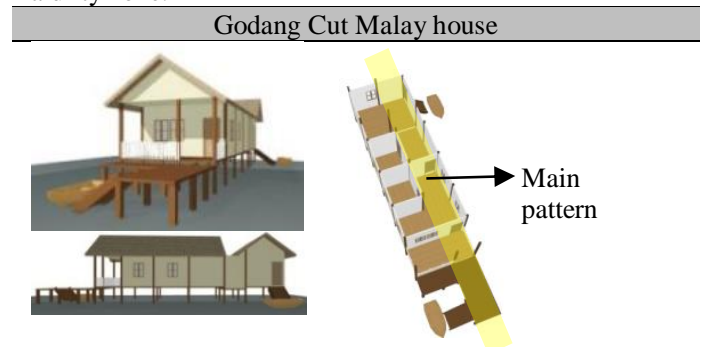

This figure consists of the main, boarding, and secondary houses. It has a pyramid-shaped roof, with a core room in the form of the front porch, living room, family room, middle room (pelantaran) and kitchen. The front terrace and living rooms consists of male and family rooms, while the middle room and kitchen are women's sections. The main house is a clean zone, middle room (pelantaran) is a transition zone for self-cleaning and the secondary home is a dirty zone.

\section{Conclusion}

This research explains the traditional Malay house architecture in West Kalimantan through variations of phenotypes. In addition, preliminary data were used to determine the original genotype and phenotype which is used to determine archetypes related to architectural identity. The results of this study found the value and meaning of the principle of spatial arrangement in the category of gender and orderliness zones from generation to generation.

\section{References}

Arinto, Fransiscus Xaverius Eddy. 2018. 'Pelestarian Arsitektur Berdasarkan Architectural Architypes Melalui Metode Grafis'. ARTEKS : Jurnal Teknik Arsitektur 3 (1): 29-36. https://doi.org/10.30822/arteks.v3i1.52.

Bafna, Sonit. 2012. 'Rethinking Genotype: Comments on the Sources of Type in Architecture. Response to Julienne Hanson's The Anatomy of Privacy in Architect' London Houses'. Journal of Space Syntax 3 (1): 6980.

http://joss.bartlett.ucl.ac.uk/journal/index.php /joss/article/view/108/pdf.

Baye, Tesfaye M, Tilahun Abebe, and Russell A Wilke. 2011. 'Genotype-Environment Interactions and Their Translational Implications'. Personalized Medicine 8 (1): 59-70. https://doi.org/10.2217/pme.10.75.

Byun, Nahyang, and Jaepil Choi. 2016. 'A Typology of Korean Housing Units: In Search of Spatial Configuration'. Journal of Asian Architecture and Building Engineering 15 (1): 41-48. https://doi.org/10.3130/jaabe.15.41.

Dyda, Iryba. 2015. 'The Concept of Traditional Architecture in Terms of Preserving Identity of Modern Arcitectural Space in Ukraine'. Architectural Studies 1 (2): 49-56. http://science.lpnu.ua/sites/default/files/journ alpaper/2017/jun/3395/irynadydatheconceptoft 
raditionalarchitectureintermsofpreservingiden tityofmodernarchitecturalspaceinu.pdf.

Eliade, M. 2003. Cosmos and History: The Myth of the Eternal Return. USA: Harper \& Brothers.

Güney, Yasemin. 2007. 'Type and Typology in Architectural Discourse'. Ballkesir Üniversitesi Fen Bilimleri Enstitüsü Dergisi 9 (1): 3-18. http://fbed.balikesir.edu.tr/index.php/dergi/art icle/view/186/169.

Hanson, J. 1998. 'The Anatomy of Privacy in Architect "London Houses". In Decoding Homes and Houses. Cambridge, England: Cambridge University Press. http://128.40.150.106/uploads/joss/DH\&H_C hapter_08.pdf.

Heidegger, Martin. 1971. Poetry, Language, Thought. New York: Harper \& Row.

Hillier, Bill. 1996. Space Is the Machine. Cambridge, England: Cambridge University Press.

Hillier, Bill, and Julienne Hanson. 1984. The Social Logic of Space. Cambridge University Press. https://doi.org/10.1017/CBO9780511597237.

Hillier, Bill, and Adrian Leaman. 1974. 'How Is Design Possible?' Journal of Architectural Research 3 (1): 4-11. https://ojs.unbc.ca/index.php/design/article/vi ew/531/468.

Ibrahim, Hatem Galal A. 2016. 'Regeneration of Sustainability in Contemporary Architecture: Approach Based on Native Function and Activities to Strengthen Identity'. Procedia Social and Behavioral Sciences 216
(January):

$800-809$. https://doi.org/10.1016/j.sbspro.2015.12.077.

Ledent, G. 2017. 'Permanence to Allow Change. The Archetypal Room'. In Architectural Research Addressing Societal Challenges, 339-44. Taylor \& Francis Group, 6000 Broken Sound Parkway NW, Suite 300, Boca Raton, FL 33487-2742: CRC Press. https://doi.org/10.1201/9781315226255-54.

Lee, Ji-Hyun, ed. 2017. Morphological Analysis of Cultural DNA. KAIST Research Series. Singapore: $\quad$ Springer Singapore. https://doi.org/10.1007/978-981-10-2329-3.

Notkin, I. I. 1988. 'GENOTYPES OF SPATIAL FORM IN THE ARCHITECTURE OF THE EAST'. Muqarnas Online 6 (1): 50-57. https://doi.org/10.1163/22118993-90000234.

Pieruschka, Roland, and Uli Schurr. 2019. 'Plant Phenotyping: Past, Present, and Future'. Plant Phenomics 2019 (March): 1-6. https://doi.org/10.34133/2019/7507131.

Sari, Indah Kartika, Wiendu Nuryanti, and Ikaputra. 2020. 'Phenotype, Genotype and Environment in Architecture Case Study: Traditional Malay House, West Borneo'. Preprints.

2020. https://www.preprints.org/manuscript/202005 $.0034 / \mathrm{v} 1$.

Seo, Kyung Wook. 2012. 'DNA of the House'. Home Cultures 9 (1): 77-97. https://doi.org/10.2752/175174212X1320227 6383850 .

2017. 'Finding Housing Genotypes by Graph Theory: An Investigation into Malay Houses'. In , 37-47. https://doi.org/10.1007/978-981-10-23293_4. 
ARTEKS : Jurnal Teknik Arsitektur, Volume 5 Issue 3 December 2020

pISSN 2541-0598; eISSN 2541-1217 